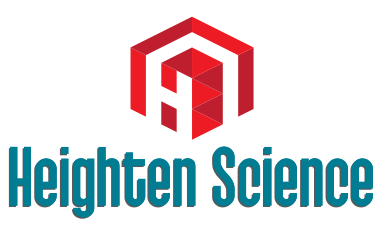

P U B L I C A T I O N S Corporation

\title{
Frequency of cytomegalovirus infection in children with Nephrotic Syndrome
}

\author{
Doaa Mohammed Youssef ${ }^{1 *}$, Mohammed Hassan \\ Mohammed ${ }^{1}$, Eman Mohammed EL-Behaidy ${ }^{2}$ and Asmaa EL- \\ Sayed Abo-warda ${ }^{1}$ \\ 'Professor of Pediatrics, Zagazig University, Egypt \\ ${ }^{2}$ Medical Microbiology \& Immunology, Faculty of Medicine, Zagazig University, Egypt
}

\begin{abstract}
*Address for Correspondence: Doaa M Youssef Professor of Pediatrics, Zagazig University, Egypt, Tel: +201222839220;

Email: dody5176@yahoo.com

Submitted: 02 May 2019

Approved: 13 May 2019

Published: 14 May 2019

Copyright: ( 2019 Youssef DM, et al. This is an open access article distributed under the Creative Commons Attribution License, which permits unrestricted use, distribution, and reproduction in any medium, provided the original work is properly cited
\end{abstract}

Keywords: CMV; Nephrotic; Children; Screening

Check for updates

\section{Abstract}

Introduction and aim: Idiopathic nephrotic syndrome (INS) is the most common type of this disease during childhood. Minimal change nephrotic syndrome (MCNS) is the most common histopathological lesion $(80-90 \%)$ of INS in children and about $90 \%$ of patients are steroid responsive, while congenital nephrotic syndrome is disorder that may be caused by several diseases. Intrauterine infections, especially CMV infection, have frequently been incriminated as etiological factors of secondary CNS. The aim of this research was to evaluate the frequency of $\mathrm{CMV}$ infection children with active nephrotic syndrome in our pediatric nephrology unit

Patients and methods: This descriptive (cross sectional) study was conducted in pediatric nephrology unit, Zagazig University Hospitals and included 60 patients WITH NS in activity; Participants were subjected to, Full history taking, Clinical examination; general \& local, Routine laboratory investigations and Serum samples were tested for HCMV specific immunoglobulin G (IgG) and immunoglobulin M (IgM) using ELISA Kit.

Results: We found $100 \%$ of cases were IgG positive and $7 / 60$ cases were IgM positive, There were no statistically significant differences between IgM positive-patients vs IgM-negative patients according to age, sex and first attack or relapsed NS, There were statistically significant differences between IgM positive-patients vs IgM-negative patients in blood laboratory data in decreases in $\mathrm{HB}(\mathrm{P}=0.024)$ and serum urea nitrogen $(P=0.04)$

Conclusion: We concluded that serofrequency of cytomegalovirus infection in pediatric nephrology unit, Zagazig university hospitals during follow-up was $12 \%$ for $\mathrm{cmv} \operatorname{lgM}$ and $100 \%$ for $\mathrm{cmv}$ IgG at ns children patients.

\section{Introduction}

Nephrotic syndrome is characterized by heavy proteinuria, ( $>40 \mathrm{mg} / \mathrm{m} 2 / \mathrm{hr}$ ), hypoalbuminemia (serum albumin $<2.5 \mathrm{~g} / \mathrm{dl}$ ), hyperlipidemia (serum cholesterol $>200$ $\mathrm{mg} / \mathrm{dl}$ ) and edema) [1]. Human CMV is a virus that infects most of the human population at some stage in their lives, officially named as human herpesvirus type 5 (HHV-5). It is a member of the Herpes viridae family, subfamily Betaherpesviridae of viruses, which includes herpes simplex virus type 1 and type 2, Varicella Zoster Virus (HHV-3), Epstein-Barr virus (HHV-4), Roseolovirus (HHV-6 and HHV-7), and Kaposi's sarcoma associated herpesvirus (HHV-8) [2]. Infection with CMV is generally asymptomatic in immunocompetent people, although clinical symptoms of primary infection can include flu-like symptoms, or occasionally persistent fever. Laboratory tests may show elevated lymphocyte counts and/or elevated liver transaminase levels [3]. Detection of CMV specific IgM in neonatal serum may also disclose congenital infection. IgM 
antibodies are only present in $20-70 \%$ of infected newborn serum [4] so, detection of CMV in a newborn older than 2-3 weeks could be the result of intrapartum or breast milk acquired infection [5]. Consequently, virological and serological tests will no longer distinguish congenital from postnatal CMV infection. So, diagnostic testing must occur within first 3-4 weeks of life, and earlier testing is best if available [6]. The role of viral infection as a trigger for onset or relapse of INS has been previously suggested. One prospective study has investigated the association of viral infection and relapses of INS, showing that $70 \%$ of relapses were preceded by viral infection. Serology and viral cultures allowed identification of respiratory syncytial virus, influenza, parainfluenza, varicella zoster, cytomegalovirus and adenovirus as potential triggers of the relapses [6]. In actuality, $\gamma$-herpesvirus (EBV), and also $\beta$-herpesviruses (cytomegalovirus and herpesvirus [6]), can build up latency in immune cells, primarily in B cells [7].

The aim of this research was to evaluate the frequency of CMV infection children with active nephrotic syndrome in our pediatric nephrology unit.

\section{Patient and Methods}

This descriptive (cross sectional) study was conducted in pediatric nephrology unit, Zagazig University Hospitals and included 60 patients in the period from January 2017 until June 2017.

60 children diagnosed as having nephrotic syndrome admitted by activity of the disease (54 cases Primary, 2 cases Secondary and 4 cases Congenital) by inclusion criteria (massive proteinuria, hypoalbuminemia, hyperlipidemia, and high cholesterol), out of 54 children with PNS recruited for the study; 47 children were steroid sensitive (SS) and 7 were non-steroid sensitive (non-SS), 47 children were relapsed, 7 children were first attack of NS.

Participants were subjected to; Full history taking (age, gender, consanguinity, family history of renal diseases). Medical records of the patients were reviewed for duration of illness and type of NS, response to the treatment, relapses, Clinical examination; general \& local, Routine laboratory investigations including renal function (S.creatinine, S.urea), urine analysis (U.albumin, U.sugar, U.RBCs and U.pus), Liver function (serum albumin, ALT and AST) complete blood picture (WBCS, S.Hb and Platletes), CRP and serum electrolytes ( $\mathrm{Na}, \mathrm{K}, \mathrm{Ca}$, and $\mathrm{Ph}$ ) were done for NS patients.

Serum samples were tested for HCMV specific immunoglobulin G (IgG) and immunoglobulin M (IgM) using HCMV IgG and IgM. ELISA Kit Bio Cheek, Ine (323 Vintage Park Drive Foster City, CA 94404).

\section{Statistical analysis}

Data were analyzed by Statistical Package of Social Science (SPSS), software version 24.0 (SPSS Inc., 2016). Continuous data were presented as Mean \pm SD if normally distributed or Median (Range) if not normally distributed. Categorical data were presented by the frequency and percentage. Normality was checked by Shapiro-Wilk test.

\section{Results}

We found that according to etiology of relapse we found 30 children were upper respiratory tract infection, 11 children were Urinary tract infection, 2 children were Gastroenteritis and 4 childeren had no precipitating factors. Out of 2 children with secondary NS recruited for the study we found one case occurred because of systemic lupus erythromatosis and the 2nd case was post glomerulonephritis due to infection with cytomegalovirus. Out of 4 children with CNS recruited for the study, only 1 case was Finnish type and the other 3cases the biopsy was not done. Our cases with age range between 2 months and 15 years with a mean age \pm SD of $75.1 \pm 50.4$ months ( 39 males, 
21 females), were tested for Cytomegalovirus IgM and IgG at time of administration. In our study we found that 7 of nephrotic syndrome children cases were CMV IgM +ve, 53 were CMV IgM -ve and all 60 screened children were CMV IgG +ve table 1.

Characteristics of the 7 of CMV IgM positive cases are presented in table 2 .

This table 3 showed non-statistically significant differences in all blood laboratory data in IgM positive-patients vs IgM-negative patients $(\mathrm{P}>0.05)$. However, there were statistically significant decreases in $\mathrm{HB}(\mathrm{P}=0.024)$ and serum urea nitrogen $(\mathrm{P}=0.04)$ in IgM positive-patients compared to IgM-negative patients.

Correlations between laboratory data and CMV IgG and IgM antibodies in the studied patients we found; Regarding to CMV IgG antibodies, no significant correlations were noticed., Regarding CMV IgM antibodies, no significant correlations were noticed except a significant negative but a weak correlation was found between IgM and HB. However, significant positive but weak correlations were found between IgM antibodies and ALT, AST \& serum K levels data not presented.

\section{Discussion}

Infection is an important cause of morbidity and mortality in nephrotic children. Patients with SSNS have increased susceptibility to bacterial infections and various infections may result in relapses or steroid resistance or may trigger the onset of disease [8].

CMV infection is also reported as a possible etiological factor in congenital, infantile, and adult NS. NS may represent another manifestation of CMV disease although the relationship between CMV infection and glomerular disease is still unclear, Also INS may developed during the course of CMV infection [9].

CMV infections are known to be very common and may be asymptomatic or cause nonspecific febrile symptoms. Less frequently, they may involve the kidneys and even cause nephrotic syndrome [10].

In our patients, the marked increase in serum CMV IgM suggested a possible viral infection, so virus might be involved in the mechanisms of NS. Here, we investigate the link between CMV infect ion and NS in children.

Table 1: Serofrequency of Cytomegalovirus (CMV) (IgG and IgM) of the studied children.

\begin{tabular}{|c|c|}
\hline \multicolumn{3}{c|}{ Variables } \\
\hline \multicolumn{3}{|c|}{ CMV IgG, $n,(\%)$} \\
\hline Positive & $60(100 \%)$ \\
\hline Negative & $0(0.0 \%)$ \\
\hline & CMV IgM, $n,(\%)$ \\
\hline Positive & $7(12 \%)$ \\
\hline Negative & $53(88 \%)$ \\
\hline
\end{tabular}

Table 2: Baseline characteristics of IgM positive patients.

\begin{tabular}{|c|c|c|c|c|c|c|c|c|c|c|c|c|c|}
\hline Case & Age & Sex & $\begin{array}{c}\text { Type of } \\
\text { nephrotic } \\
\text { syndrome (NS) }\end{array}$ & $\begin{array}{l}\text { First attack or } \\
\text { relapsed NS }\end{array}$ & $\begin{array}{l}\text { Respond to } \\
\text { steroid }\end{array}$ & $\begin{array}{l}\text { Etiology of } \\
\text { relapse }\end{array}$ & $\begin{array}{l}\text { Etiology of } \\
\text { Nephrotic } \\
\text { syndrome }\end{array}$ & $\begin{array}{l}\text { WBCs } \\
(103 / u L)\end{array}$ & $\mathrm{Hb}(\mathrm{g} / \mathrm{dl})$ & $\begin{array}{c}\text { Platelets } \\
\text { count (103/ } \\
\text { uL) }\end{array}$ & $\begin{array}{c}\text { CRP } \\
(\mathrm{mg} / \mathrm{L})\end{array}$ & $\begin{array}{l}\text { Serum } \\
\text { creatinine } \\
(\mathrm{mg} / \mathrm{dl})\end{array}$ & $\begin{array}{c}\text { Serum } \\
\text { urea } \\
\text { nitrogen }\end{array}$ \\
\hline 1. & $3 \mathrm{~m}$ & $M$ & Congenital NS & - & -- & - & No biopsy & 11.7 & 10.4 & 550.0 & 0.1 & 0.01 & 7.1 \\
\hline 2. & $13 y$ & $\mathrm{~F}$ & Primary NS & Relapsed NS & $\begin{array}{l}\text { Steroid } \\
\text { sensitive }\end{array}$ & $\begin{array}{l}\text { Urinary tract } \\
\text { infection }\end{array}$ & idiopathic & 15.5 & 10.4 & 114.0 & 6.5 & 0.4 & 23.5 \\
\hline 3. & $7 \mathrm{~m}$ & $M$ & Congenital NS & --- & --- & -- & No biopsy & 16 & 9.5 & 587.0 & 4.0 & 0.1 & 7.4 \\
\hline 4. & $8 \mathrm{~m}$ & $\mathrm{~F}$ & Congenital NS & --- & -- & --- & Finnish type & 15.7 & 11.3 & 386.0 & 0.2 & 0.3 & 3.3 \\
\hline 5. & $2 y$ & $M$ & Secondary NS & --- & -- & --- & PGN (CMV) & 11.4 & 9.0 & 397.0 & 117.0 & 3.60 & 1.0 \\
\hline 6. & $14 y$ & $\mathrm{~F}$ & Primary NS & Relapsed NS & $\begin{array}{l}\text { Steroid } \\
\text { resistant }\end{array}$ & $\begin{array}{c}\text { Urinary tract } \\
\text { infection }\end{array}$ & idiopathic & 6.40 & 12.50 & 456.00 & 0.20 & 0.10 & 17.20 \\
\hline 7. & $2 \mathrm{M}$ & $M$ & Congenital NS & -- & -- & - & No biopsy & 8.1 & 8.6 & 487.0 & 3.9 & 0.10 & 3.08 \\
\hline
\end{tabular}




\begin{tabular}{|c|c|c|c|c|}
\hline & IgM positive & IgM-negative & \multirow{2}{*}{ Significant test } & \multirow{2}{*}{$P$} \\
\hline & $n=7$ & $n=53$ & & \\
\hline Median(Range) & $11.7(6.4-16)$ & $8.5(3.6-19.9)$ & Mann-Whitney $\mathrm{U}=245$ & 0.18 \\
\hline $\mathrm{Hb}(\mathrm{g} / \mathrm{dl})$ & & & \multirow{2}{*}{$\begin{array}{c}\text { Independent samples } \\
\text { t-test }=2.3\end{array}$} & \multirow{2}{*}{0.024} \\
\hline Mean $\pm S D$ & $10.2 \pm 1.4$ & $11.6 \pm 1.5$ & & \\
\hline Platelets count $\left(10^{3} / \mathrm{uL}\right)$ & & & \multirow{2}{*}{$\begin{array}{l}\text { Independent sample } \\
\text { t-test }=0.29\end{array}$} & \multirow{2}{*}{0.8} \\
\hline Mean $\pm S D$ & $425.3 \pm 155.8$ & $409.8 \pm 131.4$ & & \\
\hline CRP (mg/L) & & & \multirow{2}{*}{ Mann-Whitney $\mathrm{U}=213$} & \multirow{2}{*}{0.5} \\
\hline Median(Range) & $3.9(0.1-117)$ & $0.5(0.1-35.6)$ & & \\
\hline Serum creatinine (mg/dl) & & & \multirow{2}{*}{ Mann-Whitney $\mathrm{U}=126.0$} & \multirow{2}{*}{0.18} \\
\hline Median(Range) & $0.1(0.01-3.6)$ & $0.3(0.03-8.5)$ & & \\
\hline Serum urea nitrogen $(\mathrm{mg} / \mathrm{dl})$ & & & \multirow{2}{*}{ Mann-Whitney $U=96.5$} & \multirow{2}{*}{0.04} \\
\hline Mean $\pm S D$ & 7.1(1-23.5) & $12(4.4-61.3)$ & & \\
\hline Serum albumin (g/dl) & & & \multirow{4}{*}{ Mann-Whitney U=212.5 } & \multirow{2}{*}{0.6} \\
\hline Mean $\pm S D$ & $2.4 \pm 0.7$ & $2.6 \pm 0.9$ & & \\
\hline AST (U/L) & & & & \multirow{2}{*}{0.5} \\
\hline Median(Range) & $24.3(17-158)$ & $22.4(10-71)$ & & \\
\hline $\operatorname{ALT}(\mathrm{U} / \mathrm{L})$ & & & \multirow{2}{*}{ Mann-Whitney U=240.5 } & \multirow{2}{*}{0.21} \\
\hline Median(Range) & $14.2(7.7-68)$ & $12(4-247.3)$ & & \\
\hline Serum $\mathrm{Na}(\mathrm{mmol} / \mathrm{L})$ & & & \multirow{2}{*}{ Mann-Whitney U=123.5 } & \multirow{2}{*}{0.15} \\
\hline Median(Range) & $138(136-141)$ & $137(127-145)$ & & \\
\hline Serum K (mmol/L) & & & \multirow{2}{*}{ Mann-Whitney U= 131} & \multirow{2}{*}{0.21} \\
\hline Median(Range) & $4.6(3.9-5.8)$ & $3.8(1.9-6.2)$ & & \\
\hline Serum Ca (mg/dl) & & & \multirow{2}{*}{ Mann-Whitney U= 185.5} & \multirow{2}{*}{$>0.99$} \\
\hline Median(Range) & $8.8(8.4-9.2)$ & $8.9(7.5-9.5)$ & & \\
\hline Serum $P(\mathrm{mg} / \mathrm{dl})$ & & & \multirow{2}{*}{ Mann-Whitney U=149.5 } & \multirow{2}{*}{0.41} \\
\hline Median(Range) & $4.6(4.3-4.8)$ & $4.6(2.6-15)$ & & \\
\hline
\end{tabular}

In our study we found that 7 (12\%) of nephrotic syndrome children cases were CMV IgM +ve, 53 (88\%) were CMV IgM -ve and all 60 screened children were CMV IgG $+v e(100 \%)$, This is in agreement with [11], who investigated Serological markers of viral, syphilitic and toxoplasmic infection in children and teenagers with nephrotic syndrome.

In our study there were non-significant differences between IgM positive-patients vs IgM-negative patients regarding age, sex and first attack or relapsed NS patients ( $p>0.05$ ); this is in agreement with [11], in their study they found. (3 cases relapsed from the 7 nephrotic children cases with cmv IgM + ve ) and 103 (60.9\%) out of the 169 nephrotic children were male but disagree regarding to age as they found the median age on the first visit was 44 months.

In our study there are highly statistically significant differences in characteristics of IgM positive-patients vs IgM-negative patients according to type of nephrotic; This also come in agreement with [12] who studied Congenital and Infantile Nephrotic Syndrome in Thai Infants in a retrospectively reviewed patients diagnosed with NS and having onset of the disease in the first year of life who presented in there were 10 patients 7 of them were tested for cmv immunoglobulin 3 of them were cmv IgM +ve and CNS.

In our study there were non-statistically significant differences between CMV IgM positive-patients vs CMV IgM-negative patients $(\mathrm{P}>0.05)$ as regarding all blood laboratory investigations (wbcs, platlete, crp, Serum create, Serum albumin, AST, Alt, serum $\mathrm{Na}$, serum $\mathrm{K}$, serum $\mathrm{Ca}$, serum $\mathrm{P}$ ). However, there were statistically significant decreases in $\mathrm{HB}(\mathrm{P}=0.024)$ and serum urea nitrogen $(\mathrm{P}=0.04)$ in IgM positive-patients compared to IgM-negative patients, This also come in agreement with Poyrazoglu et al. [13], who studied Cytomegalovirus infection and haemophagocytosis in a patient with congenital nephrotic syndrome in a 3-month-old girl. 
We concluded that serofrequency of cytomegalovirus infection in pediatric nephrology unit, Zagazig university hospitals during follow-up was $12 \%$ for cmv IgM and $100 \%$ for $\mathrm{cmv}$ IgG at ns children patients.

\section{References}

1. Bagga A, Mantan m. Nephrotic syndrome in children. Indian J Med Res. 2005; 122: 13-28. Ref.: https://tinyurl.com/yxaccv35

2. Manicklal S, Emery VC, Lazzarotto T, Boppana SB, Gupta RK. The 'Silent' Global Burden of Congenital Cytomegalovirus. Clin Microbiol Rev. 2013; 26: 86-102. Ref.: https://tinyurl.com/y3g5tc26

3. Nigro G, Anceschi MM, Cosmi EV. Congenital Cytomegalic Disease Collaborating Group. Clinical manifestations and abnormal laboratory findings in pregnant women with primary cytomegalovirus infection. BJOG. 2003; 110: 572-577. Ref.: https://tinyurl.com/y6cqt6qw

4. Revello MG, Gerna G. Diagnosis and Management of Human Cytomegalovirus Infection in the Mother, Fetus, and Newborn Infant. Clin Microbiol Rev. 2002; 15: 680-715. Ref.: https://tinyurl.com/yxf5z66n

5. Schleiss MR. Acquisition of human cytomegalovirus infection in infants via breast milk: natural immunization or cause for concern? Rev Med Virol. 2006; 16: 73-82. Ref.: https://tinyurl.com/y4do6exc

6. Centers for Disease Control and Prevention, Cytomegalovirus and congenital Infection-Interpretation of laboratory tests.2014.

7. Cohen JI. Epstein-Barr Virus Infection. N Engl J Med. 2000; 343: 481-492. Ref.: https://tinyurl.com/yyeo98gy

8. Niaudet P, Boyer O. Idiopathic Nephrotic Syndrome in Children: Clinical Aspects. Pediat Nephrol. 2009; 667-702. Ref.: https://tinyurl.com/y5y754zy

9. Giani M, Edefonti A, Damiani B, Marra G, Colombo D, et al. Nephrotic syndrome in a mother and her infant: relationship with cytomegalovirus infection. Pediatr Nephrol. 10; 1996: 73-75. Ref.: https://tinyurl.com/y6opevt8

10. Besbas N, Bayrakci US, Kale G, Cengiz AB, Akcoren Z, et al. Cytomegalovirus-related congenital nephrotic syndrome with diffuse mesangial sclerosis. Pediatr Nephrol. 2006' 201: 740-742. Ref.: https://tinyurl.com/yypr3nvr

11. Soares SF, Donatti TL, Souto FJ. Serological Markers of Viral, Syphilitic and Toxoplasmic Infection in Children and Teenagers With Nephrotic Syndrome: Case Series From Mato Grosso State, Brazil. Rev Inst Med Trop Sao Paulo. 2014; 56: 499-504. Ref.: https://tinyurl.com/y5t93wah

12. Vachvanichsanong $P$, Mitarnun $W$, Tungsinmunkong $K$, Dissaneewate $P$. Congenital and Infantile Nephrotic Syndrome in Thai Infants. Clin Pediat. 2005; 44: 169-174. Ref.: https://tinyurl.com/y3jaesbk

13. Poyrazoglu HM, Dursun I, Bastug F, Gunduz Z, Akyildiz BN, et al. Cytomegalovirus infection and haemophagocytosis in a patient with congenital nephrotic syndrome. Pediatr Nephrol. 2009; 254: 2257-2259. Ref.: https://tinyurl.com/y26yyuq7 